Zeszyty Naukowe Szkoły Głównej Gospodarstwa Wiejskiego

Ekonomika i Organizacja Gospodarki Żywnościowej nr 113, 2016: 105-116

Piotr Cyrek

Uniwersytet Rzeszowski, Wydział Ekonomii

\title{
Kluczowe cechy pracowników w rozwoju przedsiębiorstw handlowych
}

\section{Wprowadzenie}

W szerokim ujęciu handel obejmuje czynności związane z realizacją wymiany, w ramach których wyodrębnia się: negocjacje doprowadzające do zawarcia umowy kupna-sprzedaży, czynności związane ze sporządzeniem tej umowy i jej realizację. W wąskim rozumieniu handel obejmuje czynności związane $\mathrm{z}$ realizacją wymiany, ale wykonywane przez wyspecjalizowane w tej wymianie instytucje [Dietl 1991, s. 9-10]. Handel, rozumieć można także jako systematyczną wymianę produktów dokonywaną przez wyspecjalizowane w tym zakresie instytucje [Komosa 1995, s. 21]. „Zawodowe pośredniczenie w wymianie towarowej dokonywane za pomocą aktów kupna-sprzedaży" [Sławińska 1998, s. 16] stanowi istotę handlu wpisaną w jego definicję. Istnienie handlu umocowane jest więc w specjalizacji czynnika ludzkiego $\mathrm{w}$ realizacji usług handlowych, co z kolei nawiązuje do usługowej teorii handlu [Szulce 1998, s. 15-23]. Kluczową rolę w realizacji funkcji handlu ma personel sprzedażowy odpowiedzialny za szereg efektów zarówno ilościowych, jak i jakościowych swojej pracy [Moulinier 2007, s. 25].

O znaczeniu problemu właściwego doboru kadr w działalności handlowej pośrednio informuje również sama skala zatrudnienia $\mathrm{w}$ działalnościach ujmowanych w klasyfikacjach jako handel. W 2013 r. w sekcji handel i naprawy zaangażowanych było 14,9\% ogółu pracujących w gospodarce narodowej, czyli 2121875 osób, a wyłącznie w handlu detalicznym: 8,31\%, czyli 1183947 osób [Pracujacy... 2014, s. 22, 26].Nie bez znaczenia jest także udział tej sekcji w kreowaniu PKB. W 2013 r. w działalności handlowej wypracowano 16,9\% produkcji krajowej, według zaś wstępnych danych za 2014 r. udział handlu w kreacji PKB wyniósł 17\% [Rynek... 2015, s. 32]. 
Specyfika pracy realizowanej w obszarze działalności handlowej jest zgodna z typowymi charakterystykami zatrudnienia w usługach. Należą do nich zarówno feminizacja zatrudnienia, jak i elastyczność pracy, określana skalą wykorzystania form pracy niepełnoetatowej czy realizowanej $\mathrm{w}$ ramach samozatrudnienia [Cyrek M. 2012, s. 203-210]. Sytuacja ta ma jednak zarówno zalety, jak i ograniczenia związane głównie z bezpieczeństwem socjalnym realizujących pracę czy trwałością relacji pracowniczych.

Pracownicy świadczący usługi, przede wszystkim w zakresie sprzedaży, usług osobistych czy obsługi klienta byli w 2010 r. trzecią w kolejności grupą największego zainteresowania potencjalnych pracodawców [Dawid-Sawicka 2011, s. 22-24]. W 2013 roku 18,4\% stanowisk oferowanych przez pracodawców mogli zająć właśnie sprzedawcy i pracownicy usług [Górniak 2014, s. 11].

Jak wskazują wyniki „Bilansu Kapitału Ludzkiego”, 3/4 pracodawców ma jednak problemy ze znalezieniem odpowiednich pracowników $\mathrm{i}$ to nie z powodu braku kandydatów na rynku pracy, lecz z powodu ich zbyt niskich kompetencji czy doświadczenia. Pracownikom brakowało odpowiedniego przygotowania zawodowego, umiejętności organizowania pracy (kłopoty z samodzielnościa, punktualnością, starannością), a także motywacji do pracy. Zastrzeżenia wiązały się poza tym $\mathrm{z}$ umiejętnościami interpersonalnymi dotyczącymi pracy $\mathrm{w}$ grupie czy komunikatywności. Przedsiębiorcy oczekiwali przy tym zdecydowanie aktywnej, a nie pasywnej postawy [Dawid-Sawicka 2011, s. 22-24].

Ważną charakterystyką decydującą o zatrudnieniu pracownika są posiadane przez niego kwalifikacje, jednak niemal równie istotny bywa fakt znajomości czy związek pokrewieństwa z potencjalnym pracownikiem. Tendencja do zatrudniania członków rodziny obecna była także w firmach o relatywnie korzystnej sytuacji rynkowej. Prawdopodobne jest, że to dzięki determinacji całej rodziny do utrzymania źródła dochodów przedsiębiorstwa, gdzie pracowały co najmniej dwie spokrewnione osoby uzyskiwały lepsze wyniki [Cyrek P. 2014, s. 823-829]. Na sukcesy w sprzedaży wpływa ponadto szereg cech charakterologicznych pracowników obsługi klienta. Należą do nich: wytrwałość, wysoka samodyscyplina i zdecydowanie. Sprzedawca powinien być ponadto osobą konkretną, znającą swoją wartość, musi umieć nawiązywać kontakty z ludźmi, nieustannie się uczyć i wyciągać wnioski [Dworaczyński 2015, s. 18-19].

W prezentowanych badaniach weryfikacją objęto preferencje menedżerów dotyczące cech pracowników uważanych za kluczowe dla funkcjonowania firm handlowych. Wnioskowanie i uogólnienia w opracowaniu bazują na wynikach badania zrealizowanego w 300 podkarpackich podmiotach handlu detalicznego. Wywiady bezpośrednie na podstawie autorskiego kwestionariusza wywiadu, w którym zamieszczono szereg pytań zmierzających do identyfikacji elementów polityki personalnej firm w zakresie kluczowych dla funkcjonowania podmiotu 
cech pracowników przeprowadzone zostały w ostatnim kwartale 2013 i pierwszym 2014 r. Analiza objęła przesłanki oraz motywy pracodawców do konstrukcji zespołów pracowników handlowych, którzy stanowią podstawę funkcjonowania ich firm.

W artykule wykorzystano klasyczne kryteria klasyfikacji, grupując przedsiębiorstwa według: miejsca funkcjonowania, wielkości mierzonej liczbą osób pracujących oraz wysokości wskaźnika rentowności przychodów brutto. Grupy rentowności ustalono przy tym jako:

I: (od $-\infty$ do średnia-odchylenie standardowe),

II: <od średnia-odchylenie standardowe do średnia),

III: <od średnia do średnia+odchylenie standardowe),

IV: <od średnia + odchylenie standardowe do $+\infty$ ).

Kryteria te traktowane są jako obiektywne - wynikające z obiektywnych faktów bądź wysokości obliczonych wskaźników. W opracowaniu jako podstawę klasyfikacji podmiotów przyjęto także: pozycję firmy na rynku, sytuację rozwojową firmy i jej zdolności do konkurowania na otwartym rynku europejskim, ujmowane w sposób subiektywny - opisany na podstawie autooceny przedsiębiorców i ich subiektywnych odczuć.

\section{Kompetencje pracowników firm handlowych poszukiwane przez pracodawców}

Wyniki badań (tabele 1-3) wskazują na specyficzny układ kluczowych cech pracowników poszukiwanych przez pracodawców, zarówno w ujęciu ogółem, jak i w poszczególnych kryteriach klasyfikacyjnych. Menedżerowie szczególnie cenili wśród nich doświadczenie pracowników, które stanowiło podstawę poprawnej realizacji zadań sprzedażowych, ale także aktywność i własną inicjatywę pracowników oraz ich umiejętności organizacyjne. Każda z tych cech wskazywana była przez ponad połowę specjalistów zarządzających kadrą w badanych podmiotach handlu detalicznego. Występuje tu specyficzna zgodność wynikająca z logicznej konsekwencji, w której sprawna organizacja i własna aktywność pracowników budują ich doświadczenie, i odwrotnie, doświadczenie stymuluje sprawniejszą organizację. Osobom z doświadczeniem zawodowym łatwiej jest przystosować się do warunków pracy. Wymagają oni mniej czasu na adaptację. Często wymagają także mniejszej ilości szkoleń. Własna aktywność pracownika stanowić może specyficzne źródło innowacji dla przedsiębiorstwa. Obserwując procesy w firmie z perspektywy innej niż kierownictwo, pracownicy dostrzegać mogą szereg ograniczeń jej rozwoju. Kluczowe pozostaje jednak stworzenie systemu motywacyjnego, który skłoni ich do zaangażowania w poko- 


\section{8}

nanie tych problemów. Konieczność realizacji licznych zadań w krótkim czasie stawia przed pracownikami wymóg właściwej organizacji własnej pracy i takich umiejętności wymagali badani pracodawcy. Nieco rzadziej jako cechy pracowników kluczowe dla funkcjonowania firmy wskazywano umiejętności interpersonalne oraz elastyczność sprzedawców. Oczekiwanie od pracowników pierwszej linii kontaktu z klientem wysokich umiejętności w kreowaniu relacji wydaje się oczywiste, podobnie jak umiejętności szybkiej i adekwatnej reakcji na bieżącą sytuację. Pracodawcy byli przekonani o możliwości szybkiego opanowania przez pracowników umiejętności technicznych niezbędnych do realizacji transakcji handlowych, czego wyrazem był stosunkowo niewielki odsetek podmiotów ceniących u własnych pracowników właśnie umiejętności techniczne. Zaskakuje natomiast znikomy udział menedżerów traktujących jako kluczowe takie cechy, jak kierunek czy poziom wykształcenia oraz wiedzę nabytą w trakcie kursów specjalistycznych.

Wyniki te korespondują z rezultatami badań M. Cyrek [2011, s. 21] przeprowadzonych wśród ogółu przedsiębiorców realizujących działalność usługową na Podkarpaciu. W tej grupie badanych również jako najistotniejsze wskazywano doświadczenie zawodowe pracujacych, a za najmniej ważne dla funkcjonowania firmy uznano wykształcenie formalne. Rozszerzenie form działalności usługowej na sferę poza handlem łączyło się jednak ze wzrostem wagi umiejętności interpersonalnych jako cechy pracujących kluczowej dla przedsiębiorstwa. Prawdopodobnie ogólniejszy charakter tej charakterystyki lepiej korespondował z szerszym zakresem możliwych działań badanych podmiotów.

Miejsce funkcjonowania determinuje warunki prowadzenia działalności handlowej i wymagania stawiane zatrudnionym. Większy stopień zurbanizowania skorelowany jest najczęściej z szerszym rozwojem działalności handlowej, co stwarza więcej miejsc pracy w handlu. Generuje jednak również większą konkurencję wśród podmiotów handlowych, a to stymuluje z kolei wyższe oczekiwania stawiane pracownikom handlowym. Spostrzeżenia te potwierdzone zostały wynikami badań własnych (tabela 1). To właśnie w mieście bardziej kompleksowo postrzegano cechy pożądane u pracowników. Częściej zwracano uwagę zarówno na doświadczenie, własną inicjatywę, umiejętności organizacyjne, interpersonalne czy techniczne, jak i na poziom wykształcenia. Dla przedsiębiorców działających na wsi ważniejsze niż w mieście były zaś: elastyczność pracownika, kierunek jego wykształcenia oraz kursy specjalistyczne, które odbył. Największe różnice odnotowano przy tym w przypadku umiejętności interpersonalnych (7,8 pkt proc.) oraz organizacyjnych (6 pkt proc.). Większe zagęszczenie podmiotów handlowych w mieście daje klientom możliwość wyboru placówki, w której zrealizują zakupy. Większe umiejętności interpersonalne sprzedawców miały być w założeniu dodatkowym (poza klasycznymi elementami marketingu- 
Tabela 1

Kluczowe cechy pracowników (według kryteriów obiektywnych)[\%]

\begin{tabular}{|l|c|c|c|c|c|c|c|c|c|c|c|c|c|c|}
\hline \multirow{2}{*}{ Wyszczególnienie } & \multirow{2}{*}{$\begin{array}{c}\text { Ogó- } \\
\text { łem }\end{array}$} & \multicolumn{2}{|c|}{$\begin{array}{c}\text { Miejsce } \\
\text { funkcjono- } \\
\text { wania }\end{array}$} & \multicolumn{3}{|c|}{$\begin{array}{c}\text { Liczba osób } \\
\text { pracujących }\end{array}$} & \multicolumn{3}{|c|}{$\begin{array}{c}\text { Grupa rentowności } \\
\text { przychodów brutto }\end{array}$} \\
\cline { 3 - 13 } & & $\begin{array}{c}\text { mia- } \\
\text { sto }\end{array}$ & wieś & do 9 & $\begin{array}{c}10- \\
-49\end{array}$ & $\begin{array}{c}50 \\
\text { i wię- } \\
\text { cej }\end{array}$ & I & II & III & IV \\
\hline Firmy ogółem & 100,0 & 100,0 & 100,0 & 100,0 & 100,0 & 100,0 & 100,0 & 100,0 & 100,0 & 100,0 \\
\hline \multicolumn{1}{|c|}{ w tym uznające za kluczowe dla funkcjonowania firmy następujące cechy pracowników: } \\
\hline $\begin{array}{l}\text { Doświadczenie } \\
\text { zawodowe }\end{array}$ & 59,7 & 60,5 & 58,6 & 59,0 & 58,7 & 73,3 & 43,4 & 61,1 & 64,7 & 64,8 \\
\hline $\begin{array}{l}\text { Aktywność, własna } \\
\text { inicjatywa }\end{array}$ & 55,0 & 57,0 & 52,3 & 51,5 & 67,4 & 73,3 & 69,8 & 46,3 & 50,6 & 64,8 \\
\hline $\begin{array}{l}\text { Umiejętności } \\
\text { organizacyjne }\end{array}$ & 52,7 & 55,2 & 49,2 & 51,0 & 56,5 & 66,7 & 60,4 & 61,1 & 44,7 & 40,7 \\
\hline $\begin{array}{l}\text { Umiejętności } \\
\text { interpersonalne }\end{array}$ & 39,7 & 43,0 & 35,2 & 40,2 & 37,0 & 40,0 & 45,3 & 38,0 & 43,5 & 31,5 \\
\hline Elastyczność & 30,0 & 28,5 & 32,0 & 31,0 & 28,3 & 20,0 & 24,5 & 25,0 & 37,6 & 33,3 \\
\hline $\begin{array}{l}\text { Umiejętności } \\
\text { techniczne }\end{array}$ & 15,0 & 16,3 & 13,3 & 15,5 & 13,0 & 13,3 & 11,3 & 15,7 & 16,5 & 14,8 \\
\hline $\begin{array}{l}\text { Kierunek } \\
\text { wykształcenia }\end{array}$ & 4,0 & 2,9 & 5,5 & 4,6 & 0,0 & 6,7 & 3,8 & 2,8 & 5,9 & 3,7 \\
\hline $\begin{array}{l}\text { Poziom } \\
\text { wykształcenia }\end{array}$ & 2,7 & 3,5 & 1,6 & 2,9 & 0,0 & 6,7 & 3,8 & 4,6 & 1,2 & 0,0 \\
\hline $\begin{array}{l}\text { Kursy } \\
\text { specjalistyczne }\end{array}$ & 2,7 & 1,7 & 3,9 & 2,1 & 6,5 & 0,0 & 3,8 & 3,7 & 2,4 & 0,0 \\
\hline
\end{tabular}

Źródło: Obliczenia na podstawie wyników badań własnych.

mix) atutem w kreowaniu klimatu zakupów w badanych firmach. Większe oczekiwania pracodawców w odniesieniu do umiejętności organizacyjnych wynikają po części ze specyfiki form podmiotów handlowych działających w miastach i na wsi. Podmioty wiejskie bazujące na nielicznej kadrze oraz zarządzane bezpośrednio przez właściciela nie wymagały w takim stopniu jak ich miejska konkurencja skomplikowanych struktur organizacyjnych i umiejętności działania w ich ramach od swoich pracowników. Podobnie mniej zmechanizowane i słabiej wyposażone podmioty wiejskie rzadziej oczekiwały od swoich pracowników umiejętności technicznych.

Doświadczenie zawodowe jest pożądaną cechą wskazywaną przez menedżerów niezależnie od wielkości przedsiębiorstwa, jednak menedżerowie największych spośród badanych firm przywiązywali do stażu pracowników największą uwagę. Związane było to z ograniczeniem konieczności i kosztów doszkalania 
pracowników. Ważnym elementem był także fakt, że zdaniem kierownictwa doświadczeni pracownicy łatwiej i szybciej dostosowywali się do środowiska pracowniczego i zasad funkcjonowania w strukturach większej firmy. Oszczędność czasu na adaptację pośrednio przekłada się zatem na niższe koszty funkcjonowania, co przy uwzględnieniu skali działania stanowić może źródło poważnych oszczędności (większych niż w podmiotach mikro).

Wraz z wielkością firmy wzrastało znaczenie aktywności i własnej inicjatywy zatrudnionych osób. Nawet najmniejszy wkład pracownika, jego zaangażowanie, propagowanie nowych rozwiązań może wspomóc rozwój przedsiębiorstwa. Więcej takich osób kreuje więcej pomysłów czy ścieżek rozwoju. Ta cecha jest kluczowa dla największych i średnich podmiotów, a jej znaczenie malało wraz z przechodzeniem do podgrup reprezentowanych przez mniejsze podmioty, co nie oznacza, że dla podmiotów mikro jest ona bez znaczenia. Rynkowym wymogiem jest stała aktywność pracowników takich firm, która warunkuje dostosowanie podmiotu do turbulentnego otoczenia. Podobnie wraz ze wzrostem wielkości firmy mierzonej liczbą osób pracujących rosło zainteresowanie menedżerów ich umiejętnościami organizacyjnymi, które sprzyjały rozwojowi podmiotów o rozbudowanych strukturach.Elastyczność pracownika szczególnie ceniona była w firmach mikro, a jej znaczenie malało w większych podmiotach. Podobną tendencję zauważyć można w przypadku umiejętności technicznych. Podmioty mikro pozytywnie odbierały takie zdolności zatrudnianych osób częściej niż większe firmy. Największe badane przedsiębiorstwa w ogóle nie brały pod uwagę kursów specjalistycznych. Były one w stanie same zapewnić rozwój kwalifikacji pracowników, realizując szkolenia. Kierunek i poziom formalnego wykształcenia był dla nich relatywnie najczęstszym kryterium zatrudnienia pracowników, stanowiąc pierwszy ze stosowanych „filtrów” kadry.

Analiza w grupach rentowności wskazuje na rosnące znaczenie doświadczenia wraz z poprawą sytuacji ekonomicznej badanych firm. Było ono najrzadziej uznawane za kluczową kompetencję pracownika w podmiotach najmniej rentownych. Firmy te znacznie bardziej ceniły własną inicjatywę i aktywność pracowników. To w nich upatrywano rozwiązania problemów ekonomicznych, tym bardziej że również podmioty najbardziej rentowne kierowały się w doborze pracowników ich aktywnością. Wyższa rentowność przychodów brutto wiązała się z mniejszą skłonnością do kierowania się w rekrutacji handlowców umiejętnościami organizacyjnymi. Podmioty o rentowności powyżej średniej częściej doceniały elastyczność pracowników jako źródło sukcesu firmy. Relatywnie rzadziej miano cechy kluczowej dla funkcjonowania firmy przyznawano poziomowi wykształcenia oraz kursom specjalistycznym, którymi legitymowali się pracownicy firmy oraz osoby aspirujące do podjęcia w niej pracy. 
Znaczenie doświadczenia rosło wraz z pogarszaniem się subiektywnie ocenianej pozycji firmy na rynku, osiagając odsetek $66,7 \%$ firm w grupie o słabej pozycji (tabela 2). Tendencja ta została jednak zaburzona przez respondentów najkrytyczniej oceniających sytuację własnego podmiotu, wśród których przekonanie o znaczeniu doświadczenia pracowników dla funkcjonowania firmy uzyskało najniższy odsetek wskazań. Był on jednocześnie równy własnej aktywności pracowników, której znaczenie wzrastało w kolejnych podgrupach oceny pozycji rynkowej, ponownie z zaburzeniem ogólnej tendencji wśród menedżerów przedsiębiorstw dominujących na rynku. Pogarszające się opinie o pozycji firmy na rynku związane były również z malejącym znaczeniem umiejętności organizacyjnych. Właściciele podmiotów bardzo słabych rynkowo upatrywali poprawy tej sytuacji w umiejętnościach interpersonalnych oraz elastyczności własnych pracowników zarówno w relacjach z klientami, jak i w sytuacji konieczności zmiany profilu działalności firmy.

Tabela 2

Kluczowe cechy pracowników (według kryteriów subiektywnych) [\%]

\begin{tabular}{|c|c|c|c|c|c|c|c|c|c|}
\hline \multirow[b]{2}{*}{ Wyszczególnienie } & \multirow[b]{2}{*}{$\begin{array}{l}\frac{\varepsilon}{\Phi} \\
\frac{0}{0} \\
O \\
O\end{array}$} & \multicolumn{5}{|c|}{ Pozycja firmy na rynku } & \multicolumn{3}{|c|}{ Ocena sytuacji firmy } \\
\hline & & 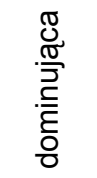 & 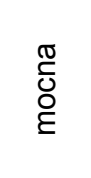 & 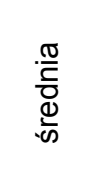 & $\frac{\frac{\pi}{2}}{\frac{\pi}{\omega \pi}}$ & $\begin{array}{l}\frac{N}{N} \\
\frac{N}{0} \frac{0}{\pi} \\
\frac{\pi}{\infty}\end{array}$ & 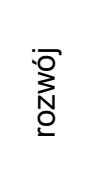 & $\begin{array}{l}\frac{\pi}{0} \\
\frac{\pi}{\pi} \\
\frac{\pi}{\pi} \\
\frac{\pi}{\omega}\end{array}$ & $\stackrel{\frac{1}{T}}{\stackrel{\mathbb{N}}{N}}$ \\
\hline Firmy ogółem & 100,0 & 100,0 & 100,0 & 100,0 & 100,0 & 100,0 & 100,0 & 100,0 & 100,0 \\
\hline \multicolumn{10}{|c|}{ w tym uznające za kluczowe dla funkcjonowania firmy następujące cechy pracowników: } \\
\hline $\begin{array}{l}\text { Doświadczenie } \\
\text { zawodowe }\end{array}$ & 59,7 & 44,4 & 53,5 & 63,5 & 66,7 & 33,3 & 53,1 & 65,4 & 54,5 \\
\hline $\begin{array}{l}\text { Aktywność, własna } \\
\text { inicjatywa }\end{array}$ & 55,0 & 44,4 & 59,6 & 53,8 & 51,5 & 33,3 & 60,8 & 51,6 & 36,4 \\
\hline $\begin{array}{l}\text { Umiejętności } \\
\text { organizacyjne }\end{array}$ & 52,7 & 55,6 & 53,5 & 53,2 & 51,5 & 0,0 & 57,7 & 51,6 & 9,1 \\
\hline $\begin{array}{l}\text { Umiejętności } \\
\text { interpersonalne }\end{array}$ & 39,7 & 66,7 & 51,5 & 32,1 & 30,3 & 66,7 & 43,1 & 37,7 & 27,3 \\
\hline Elastyczność & 30,0 & 33,3 & 29,3 & 32,1 & 15,2 & 100,0 & 26,9 & 33,3 & 18,2 \\
\hline $\begin{array}{l}\text { Umiejętności } \\
\text { techniczne }\end{array}$ & 15,0 & 0,0 & 14,1 & 17,3 & 12,1 & 0,0 & 12,3 & 16,4 & 27,3 \\
\hline $\begin{array}{l}\text { Kierunek } \\
\text { wykształcenia }\end{array}$ & 4,0 & 0,0 & 1,0 & 5,1 & 9,1 & 0,0 & 3,8 & 3,8 & 9,1 \\
\hline $\begin{array}{l}\text { Poziom } \\
\text { wykształcenia }\end{array}$ & 2,7 & 0,0 & 2,0 & 3,2 & 0,0 & 33,3 & 2,3 & 2,5 & 9,1 \\
\hline $\begin{array}{l}\text { Kursy } \\
\text { specjalistyczne }\end{array}$ & 2,7 & 11,1 & 2,0 & 3,2 & 0,0 & 0,0 & 3,1 & 1,9 & 9,1 \\
\hline
\end{tabular}

Źródło: Obliczenia na podstawie wyników badań własnych. 
Nie zaskakuje fakt, że w przedsiębiorstwach o ugruntowanej, stabilnej pozycji najważniejszą cechą pracowników było ich doświadczenie. Warunkowało ono sprawne funkcjonowanie w dotychczas wypracowanych schematach działania oraz realizację procesów i procedur zbudowanych na specjalizacji branżowej przez specjalistów z większym stażem. W firmach rozwijających się relatywnie najczęściej zgłaszano zapotrzebowanie na własną inicjatywę, umiejętności organizacyjne $\mathrm{i}$ interpersonalne pracowników, a znaczenie tych cech jako kluczowych dla funkcjonowania podmiotu malało wraz $\mathrm{z}$ tendencjami do stagnacji i zaniku firmy. W kreatywności i pomysłowości pracowników upatrywano warunków do tworzenia innowacji zarówno technologicznych, jak i organizacyjnych czy nowej konfiguracji dotychczas świadczonych usług handlowych. Pogarszające się perspektywy rozwoju wiązały się z większym zainteresowaniem umiejętnościami technicznymi, kierunkiem i poziomem wykształcenia pracowników.

Zestawienia uzyskane $\mathrm{w}$ kategoryzacji przedsiębiorców według zasięgu działania firmy (tabela 3) wskazują na rosnące znaczenie doświadczenia pracowników wraz z rozwojem obszarowo rozumianego rynku firmy, jednak jedynie dla działalności w kraju. Podobne spostrzeżenie dotyczy aktywności i własnej inicjatywy pracowników. Odwrotnie, rosnąca obszarowo skala działalności związana była z mniejszym zainteresowaniem pracodawców umiejętnościami interpersonalnymi, ponownie z zaburzeniem tej tendencji w przypadku przedsiębiorstw realizujących sprzedaż na skalę międzynarodową. Na specyfikę oczekiwań menedżerów realizujących działalność w skali międzynarodowej złożyły się relatywnie najrzadsze deklaracje uwzględniania doświadczenia i własnej aktywności pracowników. W podmiotach międzynarodowych stosunkowo najczęściej jako kluczowe kompetencje pracowników traktowano umiejętności organizacyjne oraz elastyczność pracowników, która miała znaczenie w dostosowaniu zachowania sprzedawców do sytuacji rynkowej innego kraju. Ceniono w nich również umiejętności interpersonalne, szczególnie w relacjach ze współpracownikami innej narodowości.

Uzyskane wyniki pozwalają przyjąć tezę o większym wpływie na zdolność do konkurencji na otwartym rynku Unii Europejskiej aktywności i własnej inicjatywy pracowników niż ich doświadczenia zawodowego. To właśnie podmioty deklarujące średnią bądź wysoką zdolność do konkurencji w ramach rynku europejskiego bardziej ceniły własną inicjatywę pracowników. Pomijając opinie podmiotów najmniej konkurencyjnych, wraz z poprawą autooceny zdolności do konkurowania na rynku UE można również zauważyć obniżenie zainteresowania menedżerów umiejętnościami organizacyjnymi, a wzrost interpersonalnymi. Większej zdolności do konkurencji nie wiązano przy tym z poziomem wykształcenia, które wraz z poprawą autooceny określano jako cechę pracowników kluczową dla funkcjonowania firmy coraz rzadziej. 
Tabela 3

Kluczowe cechy pracowników w kontekście integracji UE [\%]

\begin{tabular}{|c|c|c|c|c|c|c|c|c|c|}
\hline \multirow[b]{2}{*}{ Wyszczególnienie } & \multirow[b]{2}{*}{$\begin{array}{l}\frac{E}{0} \\
\frac{D}{0} \\
\delta \\
0\end{array}$} & \multicolumn{4}{|c|}{ Zasięg działania } & \multicolumn{4}{|c|}{$\begin{array}{l}\text { Zdolność do konkurencji } \\
\text { w warunkach rynku UE }\end{array}$} \\
\hline & & $\begin{array}{l}\text { 亭 } \\
\text { 毫 }\end{array}$ & $\begin{array}{l}\frac{\grave{c}}{\sigma} \\
\stackrel{0}{0} \\
\stackrel{0}{\mathbb{d}}\end{array}$ & $\begin{array}{l}\frac{3}{3} \\
\frac{0}{\pi} \\
\frac{3}{0} \\
\frac{0}{0} \\
\frac{0}{0}\end{array}$ & 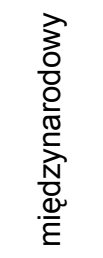 & 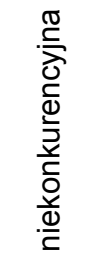 & 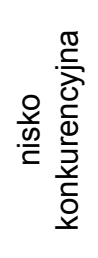 & 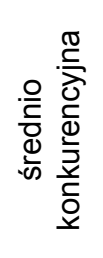 & 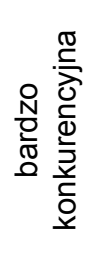 \\
\hline Firmy ogółem & 100,0 & 100,0 & 100,0 & 100,0 & 100,0 & 100,0 & 100,0 & 100,0 & 100,0 \\
\hline \multicolumn{10}{|c|}{ w tym uznające za kluczowe dla funkcjonowania firmy następujące cechy pracowników: } \\
\hline $\begin{array}{l}\text { Doświadczenie } \\
\text { zawodowe }\end{array}$ & 59,7 & 58,5 & 63,2 & 69,6 & 33,3 & 63,2 & 62,7 & 57,3 & 57,1 \\
\hline $\begin{array}{l}\text { Aktywność, } \\
\text { własna inicjatywa }\end{array}$ & 55,0 & 52,5 & 57,9 & 78,3 & 33,3 & 45,6 & 45,8 & 61,1 & 64,3 \\
\hline $\begin{array}{l}\text { Umiejętności } \\
\text { organizacyjne }\end{array}$ & 52,7 & 50,8 & 63,2 & 52,2 & 66,7 & 44,1 & 59,3 & 54,2 & 52,4 \\
\hline $\begin{array}{l}\text { Umiejętności } \\
\text { interpersonalne }\end{array}$ & 39,7 & 43,6 & 26,3 & 21,7 & 33,3 & 42,6 & 23,7 & 38,2 & 61,9 \\
\hline Elastyczność & 30,0 & 29,7 & 34,2 & 21,7 & 66,7 & 26,5 & 30,5 & 35,9 & 16,7 \\
\hline $\begin{array}{l}\text { Umiejętności } \\
\text { techniczne }\end{array}$ & 15,0 & 14,0 & 23,7 & 13,0 & 0,0 & 5,9 & 16,9 & 19,1 & 14,3 \\
\hline $\begin{array}{l}\text { Kierunek } \\
\text { wykształcenia }\end{array}$ & 4,0 & 3,4 & 7,9 & 4,3 & 0,0 & 4,4 & 5,1 & 3,1 & 4,8 \\
\hline $\begin{array}{l}\text { Poziom } \\
\text { wykształcenia }\end{array}$ & 2,7 & 2,5 & 5,3 & 0,0 & 0,0 & 4,4 & 3,4 & 2,3 & 0,0 \\
\hline $\begin{array}{l}\text { Kursy } \\
\text { specjalistyczne }\end{array}$ & 2,7 & 2,5 & 0,0 & 8,7 & 0,0 & 2,9 & 0,0 & 3,1 & 4,8 \\
\hline
\end{tabular}

Źródło: Obliczenia na podstawie wyników badań własnych.

\section{Podsumowanie}

Analiza wyników badań własnych wskazuje, że z punktu widzenia pracodawców ważniejsze są predyspozycje psychiczne niż posiadana wiedza. Podmioty najbardziej rentowne budowały efekty ekonomiczne na doświadczeniu, aktywności oraz elastyczności pracowników. Kluczowe dla uzyskania wysokich wyników ekonomicznych wydaje się zatem podejście faworyzujące charakterologiczne uwarunkowania pracownika wsparte doświadczeniem i umiejętnościami niż formalne kwalifikacje. 
Firmy o lokalnej skali działania kładły największy nacisk na doświadczenie zawodowe, własną aktywność pracowników oraz ich umiejętności organizacyjne, przyjmując te cechy za wystarczające do prowadzenia placówek handlowych. Firmy międzynarodowe zwracały natomiast uwagę na umiejętności organizacyjne i elastyczność.

O ile dla podmiotów rozwijających się kluczowe okazywały się: własna inicjatywa, umiejętności organizacyjne i interpersonalne, to firmy o pesymistycznych prognozach więcej uwagi przywiązywały do umiejętności technicznych, kierunku i poziomu wykształcenia oraz kursów specjalistycznych. Może to wskazywać na suboptymalne wyniki podmiotów, które w korzystnych warunkach pomijały dobór pracowników na podstawie ich formalnych kwalifikacji, poszukując w nich ratunku dopiero w sytuacji pogorszenia pozycji rynkowej. Firmy najbardziej konkurencyjne na rynku UE najwyżej ceniły aktywność i własną inicjatywę oraz umiejętności interpersonalne.

\section{Literatura}

CYREK M., 2011: Potencjalne kierunki dostosowania oferty ustug edukacyjnych do potrzeb rynku pracy $w$ warunkach ustugowej gospodarki opartej na wiedzy [w:] Wspótczesne wyzwania rynkowe dla kształcenia na kierunkach ekonomicznych. Raport, G. Ślusarz (red.), Uniwersytet Rzeszowski, Rzeszów.

CYREK M., 2012: Rozwój sektora ustug a gospodarka oparta na wiedzy, Wydawnictwo Uniwersytetu Rzeszowskiego, Rzeszów.

CYREK P., 2014: Decyzje rekrutacyjne w kreowaniu przewagi konkurencyjnej przedsiębiorstw handlu detalicznego, „Marketing i Rynek” nr 8/2014, PWE, Warszawa.

DAWID-SAWICKA M.,2011: Umiejętności poszukiwane i pożadane. Czego pracodawcy oczekuja od pracowników? [w:] Raport THINKTANK.

DIETL J., 1991: Handel we wspótczesnej gospodarce. Instytucje, organizacja, technologia, strategia, PWE, Warszawa.

DWORACZYŃSKI L., 2015:Rekrutacja okiem menedżera sprzedaży, „Benefit” 03(39)/2015.

GÓRNIAK J. (red.), 2014: Kompetencje Polaków a potrzeby polskiej gospodarki, Raport podsumowujacy IV edycję badań BKL z 2013 r., Polska Agencja Rozwoju Przedsiębiorczości, Warszawa.

KOMOSA A.,1995: Ekonomika i organizacja firmy handlowej. Część 1, Wydawnictwo Ekonomic, Warszawa.

MOULINIER R., 2007: Techniki sprzedaży, PWE, Warszawa.

Pracujacy w gospodarce narodowej w 2013 r., 2014: Informacje i opracowania statystyczne, GUS, Warszawa.

Rynek wewnętrzny w 2014 r., 2015: Informacje i opracowania statystyczne, GUS, Warszawa.

SŁAWIŃSKA M.,1998: Podstawy ekonomiki przedsiębiorstwa handlowego,Akademia Ekonomiczna w Poznaniu, Poznań.

SZULCE H.,1998: Struktury $i$ strategie w handlu, PWE, Warszawa. 


\title{
Abstrakt
}

Głównym celem artykułu było określenie kluczowych cech pracowników istotnych dla funkcjonowania firm handlowych prowadzaçcych sprzedaż detaliczną na obszarze województwa podkarpackiego. Realizacji tego celu podporządkowano kategoryzację firm handlowych, która miała umożliwić poszukiwanie takich cech pracowników, które pozwalały uzyskać korzystniejsze rezultaty ekonomiczne. Zweryfikowano, jakie cechy obecnych i potencjalnych pracowników odznaczają się szczególnym zainteresowaniem menedżerów podmiotów handlowych klasyfikowanych według tradycyjnych charakterystyk, takich jak miejsce funkcjonowania czy liczba osób pracujących oraz z uwzględnieniem opisu sytuacji rynkowej.

Badanie przeprowadzono, wykorzystując autorski blankiet kwestionariusza. Wywiady bezpośrednie w 300 przedsiębiorstwach handlu detalicznego przeprowadzono w dwóch kwartałach na przełomie 2013 i 2014 roku.

Analiza prowadzona jest z uwzględnieniem szeregu cech podmiotów, które przyjęto jako kryteria klasyfikacyjne. Uzyskane wyniki pozwalają na uogólnienie, że menedżerowie za kluczowe kompetencje pracowników uważają przede wszystkim doświadczenie zawodowe, aktywność, własną inicjatywę oraz umiejętności organizacyjne. Rzadko uznawano za podstawę prowadzenia działalności handlowej kierunek i poziom wykształcenia oraz kursy specjalistyczne pracowników. Podmioty o najwyższych wskaźnikach rentowności przychodów brutto, poza doświadczeniem, relatywnie częściej kierowały się w budowaniu kadr aktywnością oraz elastycznością pracowników, upatrując w nich szansy na konkurencyjność i efektywność rynkową.

Słowa kluczowe: handel detaliczny, pracownicy, kluczowe cechy pracowników, polityka personalna

\section{The key features of employees influencing the development of trade enterprises}

\begin{abstract}
The main aim of the paper was to specify features of employees that are the key ones for retailers selling products in Podkarpackie region. To do this, the retailing entities were categorized in a way allowing to search for employees' features resulting in better economic results. The enterprises were cathegorised according to the place of activity and number of employees, taking into consideration the
\end{abstract}


companies' market condition. Within these groups the features of present and potential employees that gain a special interest of managers were identified. Direct interviews were carried out, with the use of an original questionnaire form, in 300 retailing enterprises in two quarters in a turn of 2013 and 2014 year. The analysis concerns many characteristics of the entities that were adopted as classifying criteria. The results show that professional experience, active attitude, personal initiative and organizational abilities are seen by managers as key competences of the employees.

The level and type of education and professional training were rarely acknowledged as a base for retailing activity. The entities with the highest indicators of gross sale profitability were relatively more likely to consider also activity and elasticity of the employees while hiring people, as they perceived these features as a chance for rising the company's competitiveness and market efficiency.

Key words: retail trade, employees, key features of employees, personnel policy 